\title{
A dysphagia táplálásterápiája stroke-betegek esetében - 2021
}

\author{
Kovács Andrea ${ }^{1}$ - Szabó Pál Tamás ${ }^{1,2}$ - Óváry Csaba dr. ${ }^{3}$ \\ Molnár Andrea dr. ${ }^{4}$. Veresné Bálint Márta dr. ${ }^{5}$ \\ Béres-Molnár Katalin Anna dr. ${ }^{2}$ - Folyovich András dr. ${ }^{2}$ \\ ${ }^{1}$ Semmelweis Egyetem, Egészségtudományi Doktori Iskola, Budapest \\ ${ }^{2}$ Észak-Közép-budai Centrum, Új Szent János Kórház és Szakrendelő, \\ Neurológiai Osztály - Stroke Centrum, Budapest \\ ${ }^{3}$ Országos Klinikai és Idegtudományi Intézet, Budapest \\ ${ }^{4}$ Magyar Dietetikusok Országos Szövetsége, Budapest \\ ${ }^{5}$ Semmelweis Egyetem, Egészségtudományi Kar, Dietetikai és Táplálkozástudományi Tanszék, Budapest
}

\begin{abstract}
A neurológiai betegek körében a dysphagia előfordulása gyakori, és több oka van. Az utóbbi évek kutatásai a közvetlen neurológiai kórokok (beleértve a gyakori stroke) szerepét is részletesen feltárták. Felismerték az ún. néma aspiráció jelentőségét: ez gyakran áll az (aspirációs) pneumonia hátterében, amely sokszor halálos szövődmény lehet. Az ún. poststroke pneumonia fogalma gyökeresen más értelmezésbe helyezte a stroke-ot követő tüdőgyulladások megítélését, jellegzetessége alapján egyértelműen a stroke közvetlen cerebralis hatásaként alakul ki. Egyértelmúvé vált a nyelészavar korai felismerésének és ellátásának szükségessége. A stroke-betegek megfelelő tápláltsági állapota az eredményes rehabilitációnak, a szövődményszám csökkentésének, a rövidebb kórházi kezelésnek, az alacsonyabb mortalitásnak a záloga. A dysphagia a betegség kimenetelének független előrejelzője lehet, különösen az első három hónapban. A nyelészavar malnutritióval, kiszáradással és a kórházi tartózkodás hosszabb időtartamával jár együtt, emeli a gyógyszerköltségeket. A stroke-beteg ellátásának egyik első eleme a dysphagia szürése. Táplálásterápiára akkor szorul a stroke-beteg, amikor magas a kóros tápláltsági állapot kialakulásának kockázata, és per os táplálással nem fedezhető biztonságosan a megfelelő energia-, tápanyag- és folyadékbevitel. A táplálásterápia módját, eszközeit, az energia- és tápanyagbeviteli célértékeket az orvos határozza meg, az alapbetegség súlyosságától, a társbetegségektől és a laborértékektől függően. Az étrend minden esetben individuális és progresszív, azaz alkalmazkodik a beteg állapotához és annak változásához. A dietetikus feladata a megfelelő diéta összeállítása mellett a beteg, a hozzátartozó és a kezelőszemélyzet oktatása, az állapot követése, a beteg tápláltsági állapotának, tápanyagbeviteli értékeinek gyakori elemzése, szükség esetén tápszerek ajánlása.
\end{abstract}

Orv Hetil. 2021; 162(40): 1601-1609.

Kulcsszavak: stroke, malnutritio, dysphagia, pneumonia

\section{Medical nutrition therapy of stroke patients with dysphagia - 2021}

Among neurological patients, the incidence of dysphagia is common and has several causes. Research in recent years has explored the role of direct neurological pathogens (including frequent strokes). The frequency of 'silent aspiration', which often underlies (aspirational) pneumonia and can be a fatal complication, has been recently discovered. The concept of 'post-stroke pneumonia' has drastically changed the assessment of post-stroke pneumonia. Based on its characteristics, it clearly develops as a direct cerebral effect of stroke. The need for early detection and early care of swallowing disorder has become clear. Adequate nutritional status of stroke patients is the key to successful rehabilitation, reduction of complications, shorter hospitalization, and lower mortality. Dysphagia can be an independent predictor of disease outcome, especially in the first three months. Swallowing disorder is associated with malnutrition, dehydration and longer lengths of hospital stay, increasing drug costs. One of the first elements in the care of a stroke patient is screening for dysphagia. The stroke patient needs nutritional therapy when the risk for abnormal nutritional condition is high or if the condition is already present, or when oral nutrition does not safely cover adequate energy, nutrient and fluid intake. The method and means of nutritional therapy, the goals of energy and nutrient intake are determined by the doctor, depending on the severity of the underlying disease, comorbidities and laboratory values. The diet is individual and progressive in each case. The dietitian's task is not only to compile a proper diet, but also to educate the patients and relatives. The dietitian is responsible for monitoring the patient's nutritional status. 
Keywords: stroke, malnutrition, dysphagia, pneumonia

Kovács A, Szabó PT, Óváry Cs, Molnár A, Veresné Bálint M, Béres-Molnár KA, Folyovich A. [Medical nutrition therapy of stroke patients with dysphagia - 2021]. Orv Hetil. 2021; 162(40): 1601-1609.

(Beérkezett: 2021. február 8.; elfogadva: 2021. március 27.)

\section{Rövidítések}

$\mathrm{BIA}=$ (bioelectrical impedance analysis $)$ bioelektromosimpedancia-analízis; EAR = (estimated average requirement) becsült átlagos szükséglet; EBM = (evidence-based medicine) tényeken alapuló medicina; ESPEN = (European Society for Clinical Nutrition and Metabolism) Európai Klinikai Táplálkozási és Anyagcsere Társaság; ESSD = (European Society for Swallowing Disorders) Európai Társaság a Nyelési Rendellenességekért; FEES = (flexible endoscopic evaluation of swallowing) száloptikás nyelésvizsgálat; GUSS = (Gugging Swallowing Screen) 'Gugging' ágy melletti nyelésvizsgálat; VFSS = (videofluoroscopic swallow study) videofluoroszkópos nyelésröntgen-vizsgálat; $\mathrm{WST}=($ water swallowing test $)$ vízivás /víznyelés teszt

A neurológiai betegek körében a dysphagia előfordulása gyakori, és ennek több oka van. A dysphagia megjelenik súlyos általános állapot, tudatzavar esetén is, amikor a gyakorlatban strukturális idegrendszeri elváltozás nem bizonyítható. A globális keringési elégtelenség, metabolikus zavar önmagában felelős a nyelészavarért. Emellett az utóbbi évek kutatásai kiderítették, hogy sokkal több idegrendszeri struktúra és szinte minden biogén amin szerepet játszik a folyamatban [1]. Ez magyarázza azt, hogy a korábbi ismereteink alapján várhatónál sokkal nagyobb a dysphagia előfordulása. Igaz persze az is, hogy a nyelészavar felismerésének folyamata is bővült. A nyelészavar vizsgálatának fontosságát hangsúlyozva, már az egyszerü fizikális vizsgálatok, az ún. ágy melletti szứrések révén felismerték a müködészavart olyan betegeknél is, akiknél nem gondoltak volna rá korábban. Ráadásul a talán legveszélyesebb kórkép, az ún. néma aspiráció kiszưrése is lehetővé vált. Ezzel párhuzamosan a müszeres nyelésvizsgálatok (VFSS - videofluoroscopic swallow study [nyelésröntgen], FEES - flexible endoscopic evaluation of swallowing [száloptikás nyelésvizsgálat]) is elterjedtek, így további betegeknél igazolható a dysphagia. Ez törvényszerűen eredményezte, hogy a nyelészavar felismerése és kezelése multidiszciplináris megközelítésǔvé vált.

Ennek a folyamatnak látszólag ellentmond, hogy kevés az átjárás az egyes orvosszakmák között ezen a területen. Magyarországon is szinte az utolsó 5 évben jelentek meg ezzel foglalkozó előadások; 2017-ben kerültek adaptációra, majd 2020 elején aktualizálásra a stroke-betegek táplálásterápiájával foglalkozó nemzetközi irányelvek. De a kérdés fordítva is igaz: a táplálástudománnyal foglalkozó szakemberek közül kevesen vizsgálják a neu- rológiai vonatkozású témákat. Példaként: az ESPEN (European Society for Clinical Nutrition and Metabolism) 2017. évi kongresszusán (Hága, 2017. szeptember 9-12.) az elhangzott előadások száma 328, a posztereké 740, együtt 1068 volt. Ebből a neurológiai vonatkozású előadások, poszterek (beleértve 1 továbbképző ülést) száma 18 (1,69\%) volt. Ezt tovább elemezve, stroke-kal mindössze 5, Parkinson-szindrómával 1 , izombetegséggel 2, sclerosis multiplexszel 1 prezentáció foglalkozott. Érdekes, hogy pszichiátriai kórképekkel 18 munka jelentkezett. Az ESSD (European Society for Swallowing Disorders) kongresszusa (Barcelona, 2017. szeptember 18-19.) sokkal jobb képet mutatott, a 318 előadás, poszter közül neurológiai vonatkozású 92 (28,9\%) volt, ennek közel egyharmada stroke témájú. Mindebből az következik, hogy az enteralis táplálással foglalkozók számára nemzetközi téren is mostoha területnek látszik egyelőre a neurológia. A stroke-betegek ellátására vonatkozóan részletesen kidolgozott szakmai irányelvek állnak rendelkezésre szerte a világon $[2,3]$. Ezek ugyanúgy egyértelmúen leírják akut stroke esetében a kivizsgálás menetét a laboratóriumi vizsgálatoktól a képalkotó vizsgálatokig, mint a tényeken alapuló medicina (evidencebased medicine - EBM) bizonyította gyógyszerek alkalmazását. Hosszú időn át „mostohagyerek” volt e téren a táplálásterápia, de 2017 óta Magyarországon is rendelkezésre áll ez a speciális irányelv [4]. Ez önmagában jelzi, hogy a stroke-beteg ellátásának folyamatában ugyanolyan súllyal esik latba a megfelelő táplálás (beleértve a folyadékbevitelt), mint az ellátás más mozzanata.

A mozgásukban sokszor komolyan korlátozott betegek megfelelő gyógytornáztatása alapvetően javítja a kezelés kimenetelét, ugyanakkor esetleg további energiaigényt generál. Az ún. „stroke unit”-ok (stroke-centrumok, szakmaspecifikus őrzők) bizonyítottan eredményesebb ellátást biztosítanak egy „átlagos” osztályhoz képest [5]. A stroke-betegek gyógyítását végző összeszokott csapat magában foglalja minden szakterület képviselőjét (így a dietetikust is), biztosítva ezáltal a teljes körű szakszerü kezelést.

Stroke-betegeknél is egyértelmúek a táplálásterápia eredményei (jobb kimenetel, kevesebb szövődmény, kisebb antibiotikumigény, rövidebb kórházi tartózkodás stb.). Kényszerű ellenérv szokott lenni, hogy a finanszírozási lehetőségek nem teszik lehetővé például a tápszerek beszerzését. Eddigi vizsgálatok szerint rendkívül precíz és munkaigényes adminisztráció, dietetikus aktív közremúködése mellett biztosítható az ellátás ezen a té- 
ren is. Tény azonban, a táplálás költségigényét komplexen kell szemlélni, más, az akut stroke-ellátásban finanszírozott módszerekkel együttesen kell megítélni, elismerni.

Munkánk célja az volt, hogy 2020 ismereteit, lehetőségeit összefoglaló tanulmányban mutassuk be az akut stroke-betegek enteralis táplálására vonatkozóan. Az egyes részek és a szerzők személye bizonyítja, hogy a korszerű ellátás teammunkában valósítható meg.

\section{Stroke és dysphagia}

A stroke a világon a második leggyakoribb halálok, és a vele összefüggő halálozások gyakorisága is növekszik, így napjainkban az egészségügyi ellátórendszer egyik legnagyobb kihívása a stroke-betegek eredményes ellátása (ennek meghatározó része a beteg megfelelő táplálása). Magyarországon és az egyéb vizsgált országokban (egyéb európai uniós országok, Norvégia, Svájc) az Egészségügyi Világszervezet becslése szerint a strokeesemények száma a 2000. évi 1,1 millióról 2025-re évente több mint 1,5 millióra emelkedhet, kizárólag a demográfiai változások miatt [6]. A stroke előfordulása az életkor előrehaladtával növekszik, és a legtöbb vizsgált országban a férfiak esetében magasabb az incidenciája [6].

A Cseh Köztársaság, Görögország és Portugália mellett Magyarországon is a nők esetében magasabb a stroke prevalenciája [6].

Az agyi érkatasztrófán átesett betegek a mindennapjaikat fogyatékossággal és akadályozottsággal élik [7]. Az izomgyengeség és a fizikai múködés zavara a kritikus állapotú betegség gyakori és hosszan tartó szövődménye [8]. A stroke után hat hónappal a túlélók 9-21\%-a súlyos fogyatékossággal, intézményben éli mindennapjait, teljes mértékben mások gondoskodásától függően [9]. Ezek a károsodások hatással vannak a túlélők mindennapi életére és életminőségére. Negatívan befolyásolják önbizalmukat, fizikai aktivitásukat, önállóságukat, függetlenségüket és családi kapcsolataikat [10]. Életminőségük hanyatlása negatív hatással van tápláltsági állapotukra is. De ez a hatás kölcsönös. A stroke-betegek többsége nem felel meg az EAR-nak (estimated average requirement) a tápláltsági állapottal kapcsolatos becsült, átlagos, napi szükségleteknek, így hajlamos az elégtelen táplálkozás következtében kialakult, jelentős mértékű szövetvesztésre és malnutritióra. Korábbi tanulmányok szerint a malnutritio aránya 6,1\% és 49\% között változott az életmentés fázisában vizsgált stroke-túlélők esetében [11]. A stroke-betegek tápláltsági állapota nagymértékben befolyásolja rehabilitációjuk hatásfokát, betegségük kimenetelét és mortalitási mutatóikat. Számos kockázati tényező mellett a dysphagia is jelentősen hozzájárulhat alultápláltságukhoz, amikor a nyelési nehezítettség miatt a napi tervezett étrendet nem vagy csak részlegesen tudják betartani. A dysphagia a stroke gyakori tünete, egyúttal szövődménye, bár előfordulásáról szélsőséges adatok láttak napvilágot. Független előrejelzője lehet, hogy a stroke-on átesett beteg otthonába bocsátható-e, vagy intézményi ellátásra szorul az első három hónapban. Emellett a szondatáplálást igénylő, súlyos fokú nyelészavar szoros összefüggést mutat a mortalitással.

A nyelészavar stroke-ot követő diagnosztizálása elengedhetetlen része a terápiának, mert megelőzheti a pne-

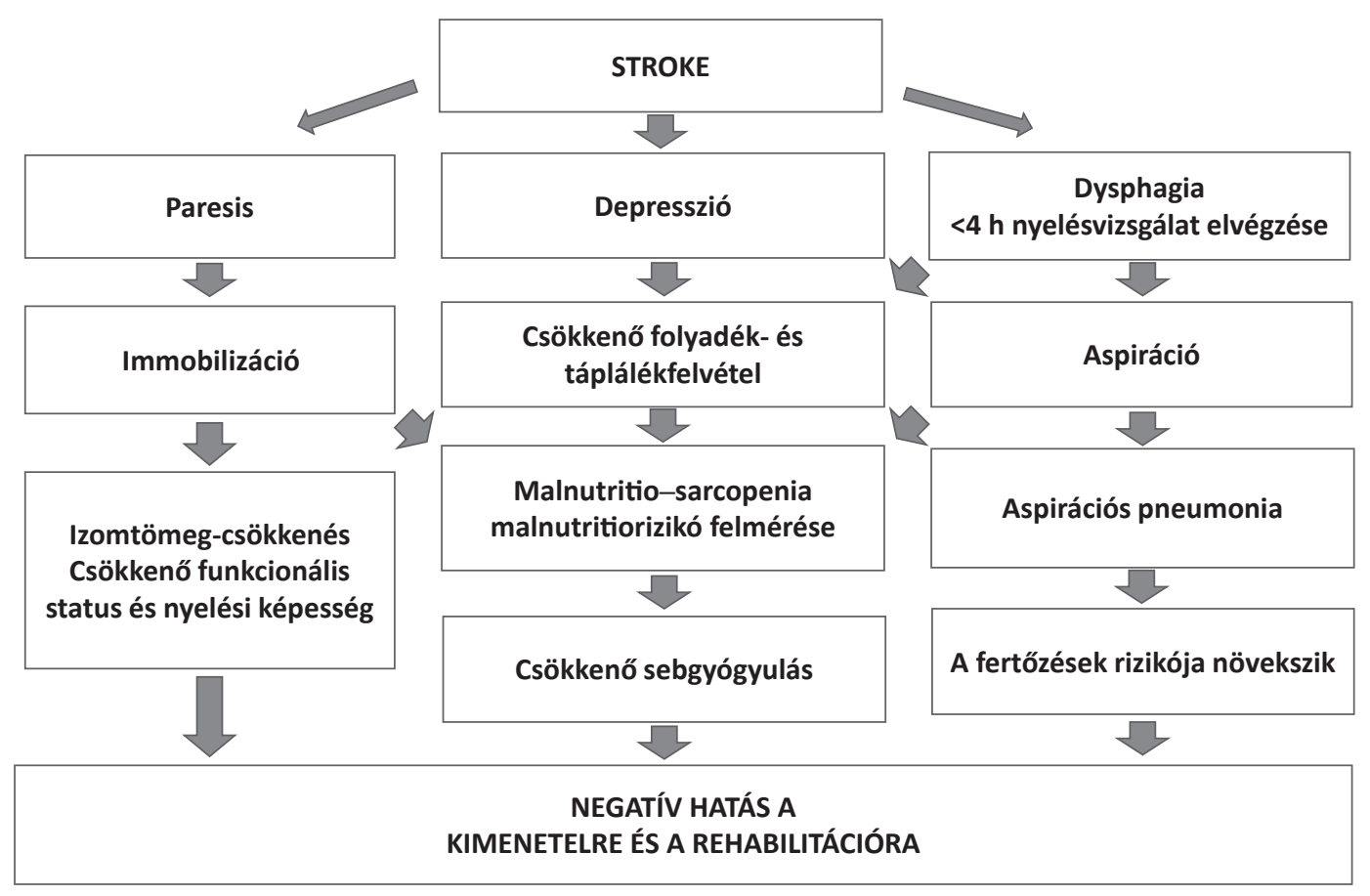


umoniát, amely a stroke utáni első napokban jelentkezik, és csökkentheti az akut fázisra jellemző, fokozott mortalitási kockázatot. A dysphagia malnutritióval, exsiccosissal és a kórházi tartózkodás hosszabb időtartamával jár együtt [12]. A súlyos szövődmények mellett emeli a gyógyszerköltségeket (például antibiotikumok), ami extra kiadással terheli az egészségügyi intézményeket. Az ellátórendszer túlterheltsége és a dysphagiaszúrés hiánya miatt a stroke-on átesett betegeknél a gyógyszeres és a mütéti beavatkozások hatékonysága a gyógyulási és rehabilitációs folyamatokra a dysphagia következtében csökken. A stroke-ot követő szövődmények negatív hatását a kimenetelre és a rehabilitációra az 1 ábra mutatja be.

\section{A stroke-betegek dysphagiaszürésének folyamata}

A stroke-beteg ellátásának egyik első és igen fontos eleme a dysphagia szürése, amely valamennyi esetben elvégzésre kell, hogy kerüljön a betegfelvételkor vagy azt követően néhány órán belül. Az egyik legszélesebb körben elterjedt szúrőeljárás a vízivás/víznyelés teszt (WST water swallowing test), amelynek többféle változata ismert, de alapelve ugyanaz: a beteggel vizet kell itatni. A víz mennyiségétől függően változik a teszt szenzitivitása és specificitása, azonban $1 / 2-1$ deciliter víz folyamatos ivásának akadályozottsága már előre jelezheti a dysphagiát [13]. Célja megállapítani azt, hogy a beteg a továbbiakban képes lesz-e a per os táplálkozásra, képes lesz-e önállóan a kellő mennyiségű folyadék és tápanyag bevitelére. A nyelések egymáshoz viszonyított késése (konszekutív vagy szekvenciális/ismétlődő nyelésmintázat [14]), a mozgásminták koordinációs zavara a vízivásteszt során könnyen megfigyelhető, azonban körültekintéssel alkalmazandó eljárás. Fontos anamnesztikus adat, hogy a beteg mikor étkezett, vagy fogyasztott folyadékot utoljára.

Szintén gyanújel lehet a korábbi gépi lélegeztetés, a visszatérő pneumonia, a gyakori félrenyelések vagy köhögések táplálkozáskor, illetve a súlyvesztés, az étkezések időtartamának megnyúlása [15]. A táplálékfelvételben szerepet játszó izomcsoportok, idegek vizsgálatát követően funkcióvizsgálat történik. Ez az elővizsgálattal és az

1. táblázat |A stroke-betegek dysphagiadiagnosztikájának folyamata

\begin{tabular}{|c|c|c|c|c|c|}
\hline Lépés & Alanya & Ideje & Módja & Elemei & Célja \\
\hline \multirow[t]{2}{*}{ 1. Szúrés } & \multirow[t]{2}{*}{$\begin{array}{l}\text { Valamennyi akut } \\
\text { stroke-beteg }\end{array}$} & \multirow[t]{2}{*}{ Betegfelvételkor } & $\begin{array}{l}\text { Anamnesztikus } \\
\text { kérdések }\end{array}$ & $\begin{array}{l}\text { Korábbi gépi lélegeztetés, } \\
\text { visszatérő pneumonia, } \\
\text { gyakori félrenyelés/köhögés } \\
\text { étkezéskor, az étkezések } \\
\text { időtartama emelkedett, stb. }\end{array}$ & Felmerül-e a dysphagia veszélye? \\
\hline & & & $\begin{array}{l}\text { Vízivás/víznyelés } \\
\text { teszt } \\
\text { (WST - water } \\
\text { swallowing test) }\end{array}$ & $\begin{array}{l}\text { Kb. } 50 \mathrm{ml} \text { folyadék folyama- } \\
\text { tos itatása }\end{array}$ & $\begin{array}{l}\text { Felmerül-e a dysphagia veszélye? } \\
\text { Képes lesz-e a beteg a napi } \\
\text { szükséges folyadékmennyiség per } \\
\text { os bevitelére? Szükséges-e } \\
\text { szondatáplálás? }\end{array}$ \\
\hline \multirow[t]{2}{*}{$\begin{array}{l}\text { 2. A nyelészavar } \\
\text { felmérése }\end{array}$} & \multirow[t]{2}{*}{$\begin{array}{l}\text { A szúrésen } \\
\text { dysphagia- } \\
\text { veszélyeztetett- } \\
\text { nek minősített } \\
\text { beteg }\end{array}$} & \multirow[t]{2}{*}{$\begin{array}{l}\text { Lehetőség szerint } \\
24 \text { órán belül }\end{array}$} & \multirow{2}{*}{$\begin{array}{l}\text { Ágy melletti } \\
\text { nyelésvizsgálat } \\
\text { (nem múszeres, } \\
\text { például GUSS } \\
\text { - Gugging } \\
\text { Swallowing } \\
\text { Screen) }\end{array}$} & $\begin{array}{l}\text { Indirekt nyelésvizsgálat } \\
\text { (éberség, utasítások } \\
\text { követése, a nyeléshez } \\
\text { szükséges oromotoros } \\
\text { funkciók vizsgálata stb.) }\end{array}$ & $\begin{array}{l}\text { A biztonságos nyelés előfeltétele- } \\
\text { inek ellenőrzése }\end{array}$ \\
\hline & & & & $\begin{array}{l}\text { Direkt nyeléspróbák több } \\
\text { konzisztenciával }\end{array}$ & $\begin{array}{l}\text { A dysphagia súlyosságának } \\
\text { megítélése. A biztonságosan } \\
\text { fogyasztható állag meghatározása }\end{array}$ \\
\hline \multirow[t]{2}{*}{$\begin{array}{l}\text { 3. A nyelészavar } \\
\text { múszeres } \\
\text { vizsgálata }\end{array}$} & \multirow[t]{2}{*}{$\begin{array}{l}\text { Dysphagiás } \\
\text { beteg }\end{array}$} & \multirow[t]{2}{*}{$\begin{array}{l}\text { Az ágy melletti } \\
\text { nyelésvizsgálat } \\
\text { és a kezelési terv } \\
\text { függvényében }\end{array}$} & $\begin{array}{l}\text { Száloptikás } \\
\text { nyelésvizsgálat } \\
\text { (FEES - flexible } \\
\text { endoscopic } \\
\text { evaluation of } \\
\text { swallowing) } \\
\text { és/vagy }\end{array}$ & $\begin{array}{l}\text { Strukturális és funkcionális } \\
\text { vizsgálat nyugalmi } \\
\text { állapotban és nyelés közben }\end{array}$ & $\begin{array}{l}\text { A strukturális és funkcionális } \\
\text { elváltozások megállapítása. } \\
\text { A dysphagia súlyosságának } \\
\text { meghatározása. A biztonságosan } \\
\text { fogyasztható állag megítélése }\end{array}$ \\
\hline & & & $\begin{array}{l}\text { Nyelésröntgen } \\
\text { (VFSS - video- } \\
\text { fluoroscopic } \\
\text { swallow study) }\end{array}$ & & \\
\hline \multirow[t]{2}{*}{ 4. Kontroll } & \multirow[t]{2}{*}{$\begin{array}{l}\text { Dysphagiás } \\
\text { beteg }\end{array}$} & $\begin{array}{l}\text { Lehetőség szerint } \\
\text { naponta }\end{array}$ & $\begin{array}{l}\text { Ágy melletti } \\
\text { nyelésvizsgálat }\end{array}$ & Lásd: 2. lépés & \multirow[t]{2}{*}{$\begin{array}{l}\text { A nyelészavar folyamat- } \\
\text { diagnosztikája }\end{array}$} \\
\hline & & $\begin{array}{l}\text { Szülkség esetén, } \\
\text { a kezelési terv } \\
\text { függvényében }\end{array}$ & $\begin{array}{l}\text { Müszeres } \\
\text { nyelésvizsgálat }\end{array}$ & Lásd: 3. lépés & \\
\hline
\end{tabular}


indirekt nyelési próbákkal kezdődik. A felmérés során a betegnek legalább 15 percig fenn kell tudnia tartani az éberségét, követnie és végre kell tudnia hajtani utasításokat. A légútvédelem aktív eleme a köhögés és a torokköszörülés. Ezeket a betegnek kérésre produktívan végre kell tudnia hajtani. A vizsgálat során figyelni kell a spontán megjelenő nyeléseket, azok gyakoriságát. Tízperces időablakban négy vagy annál kevesebb nyelés már szenzitív előrejelzője a dysphagiának [16]. Ezt követően a száraz nyelési próba jön. Az ismételt akaratlagos nyelési tesztben legalább hármat kell tudnia nyelni a betegnek fél perc alatt [17]. A szájtérból kicsurgó nyál (drooling) az oralis kontroll zavarára (saliva management) utal, ami szintén hívójel. Felmérésünk során a beteg hangszíne, annak változása (nedves, gurgulázó hang) utalhat a leginkább arra, hogy a váladék eléri a hangrést (penetráció), vagy annak szintje alá kerül (aspiráció). A nyelést követő tiszta fonáció jelzi, hogy a lenyelt nyál valószínúleg nem ment félre [18]. Amennyiben eddig valamennyi próba/ megfigyelés negatív, megkezdhetők a direkt nyelési próbák. Ennek során három, kötött sorrendú állaggal (1) püré sürüségü folyadék $\rightarrow 2$ ) híg folyadék $\rightarrow 3$ ) szilárd) vizsgáljuk a beteg nyelését. Ha a próbák során egy is megjelenik az aspiráció négy hívójele közül (sikertelen/ megkésett nyelés; önkéntelen köhögés; drooling; hangszínváltozás), a próbát megszakítjuk, és a vizsgálat eredményét kiértékeljük. Az itt ismertetett eljárás a Gugging Swallowing Screen (GUSS) lépéseit követi [19]. Magyar nyelvre történő adaptációja az Észak-Közép-budai Centrum, Új Szent János Kórház és Szakrendelő Neurológiai Osztályának Stroke Centrumában zajlik, a folyamatot a szerzők engedélyezték.

A nyelészavar felmérését mûszeres vizsgálatok egészíthetik ki. A leggyakrabban alkalmazott (arany standard) a FEES és a VFSS [20]. További értékes adatokkal szolgálhat az ultrahangos nyelésvizsgálat [21] vagy a perioralis izomzat nyomáserejének mérése is [22], azonban az aspiráció pulzoximéterrel történő detektálásának megbíz- hatósága - az elterjedt klinikai alkalmazás ellenére - erősen vitatott [23]. A stroke-betegek dysphagiadiagnosztikájának egyszerúsített összefoglalóját az 1. táblázat tartalmazza.

\section{Személyre szabott táplálásterápia stroke- betegeknél}

Táplálásterápiára akkor szorul a stroke-beteg, amikor magas a kockázata a kóros tápláltsági állapot kialakulásának, vagy már ki is alakult a kóros állapot, és per os táplálással nem fedezhető biztonságosan a megfelelő energia-, tápanyag- és folyadékbevitel [24-26].

Ebben a betegcsoportban gyakoriak a következő kóros tápláltsági állapotok: malnutritio, sarcopenia, sarcopen obesitas. A diagnosztizálásukhoz szükséges a tápláltsági állapot felmérése és a testösszetétel analizálása [24, 25]. Régen paresis esetén problémát okozott a testtömeg mérése és a fekvő betegnél a testösszetétel mérése. Ma már a modern ágymérlegek segítségével könnyen megmérhető az állás-ülés képtelen beteg testtömege, és a modern, mobil, ágyban is használható BIA- (bioelektromosimpedancia-analizáló) eszközök segítségével a testösszetétel is könnyedén felmérhető. A BIA-módszer alapja az emberi test elektromos áramot vezető és módosító képessége. Az eszközök a végtagokra kapcsolt érintkezők közötti ellenállás komplex értékét (az impedanciát) mérik, és a mért impedanciaértékekből megbecsülhetők a testre jellemző összetételi adatok. Az előbbiek szemléltetésére szolgál a 2. ábra [27-32].

A becslés pontosságát jelentősen javítja, ha a mérés több frekvencián, öt szegmensben, nyolcpontos érintkezéssel történik. A klinikumban napjainkban is használatos BIA-eszközök véleményezését mutatja be a 2. táblázat $[30,32]$.

A BIA-vizsgálatnál a beteg-előkészítés a pontos, precíz mérés első lépése: a vizsgálat szobahőmérsékletú
Emberi test

(+bemeneti adatok: nem, életkor, magasság, testtömeg)

\section{Bioelektromosimpedancia-} analizátor

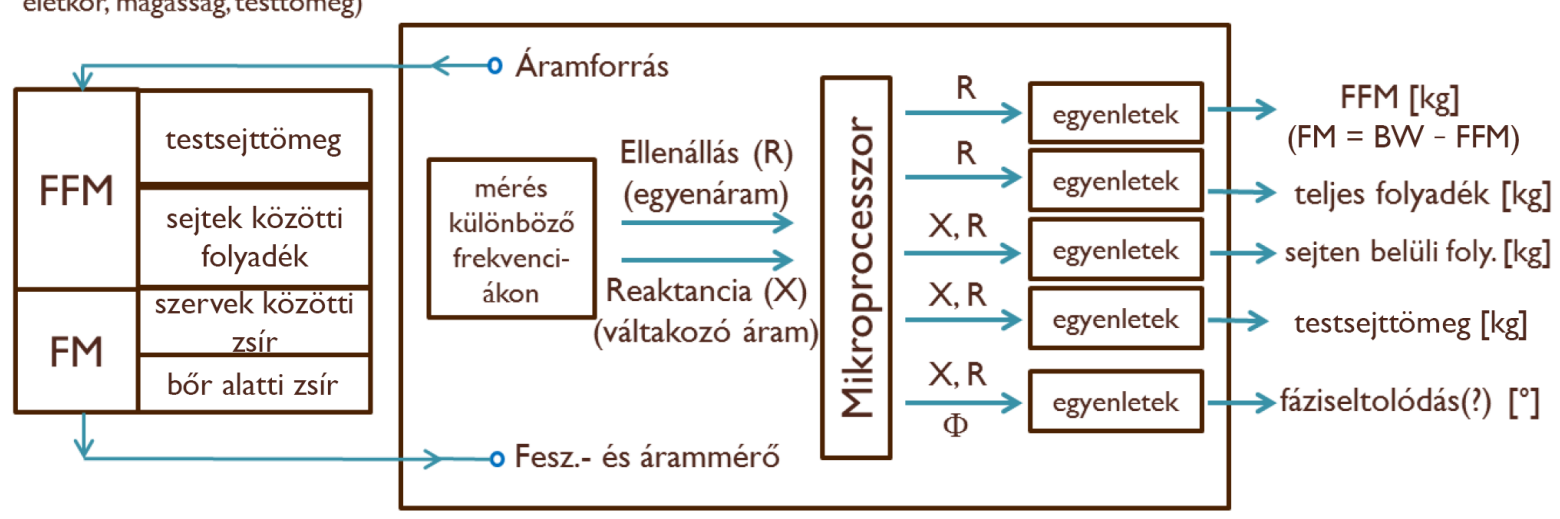

\section{Kimeneti} adatok

2. ábra

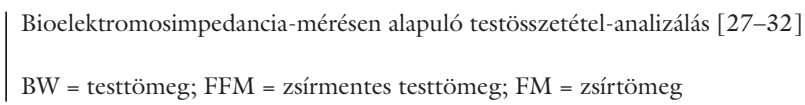


2. táblázat |A klinikumban használatos BIA-eszközök véleményezése [30, 32]

\begin{tabular}{|c|c|c|}
\hline Készülékek & Mérési jellemzók & Előnyök és gyengeségek \\
\hline $\begin{array}{l}\text { Alapkészülék } \\
\text { (Body Composition Monitor) }\end{array}$ & $\begin{array}{l}\checkmark \text { Teljes test vagy végtagok közötti } \\
\text { impedanciát mér, egyetlen frekvencián } \\
\checkmark 2 \text { vagy } 4 \text { pontos érintkezó elektródákkal } \\
\quad \text { (gyenge reprodukálhatósággal) }\end{array}$ & $\begin{array}{l}\checkmark \text { Olcsó } \\
\checkmark \text { Kevés paramétert kalkulál: BMI, izom\%, zsír\% } \\
\checkmark \text { Ödémát nem jelez }\end{array}$ \\
\hline $\begin{array}{l}\text { Félprofesszionális készülékek } \\
\text { (Body Composition Analyser) }\end{array}$ & $\begin{array}{l}\checkmark \text { Teljes test impedanciát mér, különböző } \\
\text { frekvenciákon } \\
\checkmark 4 \text { vagy } 8 \text { pontos érintkező elektródákkal }\end{array}$ & $\begin{array}{l}\checkmark \text { Számos paramétert kalkulál: FFM, FM, SMM stb. } \\
\checkmark \text { Eszköztől függő́n az ödéma jelenlétét mutathat- } \\
\quad \text { ja, de a súlyosságát nem }\end{array}$ \\
\hline $\begin{array}{l}\text { Professzionális készülékek } \\
\text { (Segmental Body Composition Analyser) }\end{array}$ & $\begin{array}{l}\checkmark 5 \text { szegmensekre bontott méréseket végez, } \\
\text { különbözö frekvenciákon } \\
\checkmark 8 \text { pontos érintkezó elektródákkal } \\
\quad \text { (jó reprodukálhatósággal) }\end{array}$ & $\begin{array}{l}\checkmark \text { További paramétereket is kalkulál, pl.: FFMI, } \\
\text { FMI, PA } \\
\checkmark 5 \text { szegmensben mutatja az ödéma jelenlétét, } \\
\text { súlyosságát } \\
\checkmark \text { Drága }\end{array}$ \\
\hline
\end{tabular}

BIA = bioelektromosimpedancia-analízis; BMI = testtömegindex; FFM = zsírmentes testtömeg; FFMI = zsírmentestesttömeg-index; FM = zsírtömeg; FMI = zsírtömegindex; PA = fázisszög; SMM = vázizomtömeg

helyszínen történjen, a páciens legyen reggel éhgyomorra, vizeletürítés és lehetőleg székletürítés után. A mérés fehérnemüben (zokni, harisnya, fém ékszerek, szemüveg nélkül) történjék, a beteg előtte ne végezzen megerőltető fizikai aktivitást, nőknél kerülendő a menstruációs időszak [28, 30]. Figyelni szükséges a megfelelő testhelyzetre (elhelyezkedés a méröpontokon, a karok ne érjenek a törzshöz, és ne legyenek behajlítva, stb.). A mérési eredményt befolyásolhatja: generalizált ödéma és lokális folyadékfelszaporodás (például ascites, végtagi ödéma), abnormális elektoritszint, parenteralis tápoldat vagy folyadék bevitele, dialízis, gyógyszerek, melyek kihatással lesznek a folyadékháztartásra, például szteroid, növekedési hormon, diuretikumok, implantátumok (például fém, szilikon) [28, 30]. Nem javasolt a mérést elvégezni (vagy csak szigorú orvos felügyelet mellett), amennyiben a betegnél pacemakerbeültetés történt [28]. A BIA-vizsgálat nemcsak a kóros tápláltsági állapot felmérésére, hanem az alapanyagcsere zsírmentes testtömegen alapuló meghatározására, valamint a személyre szabott táplálásterápia során a hatékonyág pontos követésére is alkalmas [31, 32].

Az elmúlt években már Magyarországon is elérhetővé váltak az indirekt kalorimetriás eszközök, amelyek segítségével pontosan meghatározható a beteg nyugalmi alapanyagcseréje. A tápláltsági állapot, a testösszetétel eredménye és az energiaigény mellett még a dysphagia jelenlétét és súlyosságát is ismerni szükséges ahhoz, hogy a betegnek a személyre szabott táplálásterápia elrendelhető legyen. A táplálásterápia módját, eszközeit, az energia- és a tápanyagbeviteli célértékeket az orvos határozza meg, az alapbetegség súlyosságától, a társbetegségektől és a laborértékektől függően.

A dietetikus segíthet az orvosnak a speciális, gyógyászati célra szánt, per os fogyasztható élelmiszerek (régi nevükön tápszerek) vagy az optimális szondatermék kiválasztásában. A táplálásterápia szempontjából ki kell emelni azokat a súlyos stroke-betegeket, akik eszméletlen állapotban gépi lélegeztetésre szorulnak az intenzív terápiás osztályon. Ideális esetben az intubálással egy időben megtörténik a nasogastricus szonda lehelyezése, és modern táplálópumpa segítségével folyamatos táplálási móddal, kifejezetten a kritikus állapotú betegek számára kifejlesztett, magas fehérje- és moderált energiatartalmú szondatermékkel táplálásterápiában részesülnek [33]. A személyre szabott szondatermék kiválasztásakor válogathatunk a kiegyensúlyozott összetételű, különböző mértékben megnövelt fehérjetartalmú és a betegségspecifikusan kifejlesztett termékek között. A kiválasztásánál nemcsak a főbb tápanyagok mennyiségét és egymáshoz viszonyított arányát érdemes vizsgálni, hanem az aminosav-, a zsiradék- és a szénhidrátprofilt, valamint a rostoknál a vízoldékony és a vízben nem oldódó rostok arányát is.

\section{A dysphagia dietoterápiája}

$\mathrm{Az}$ étrend minden esetben individuális és progresszív, azaz alkalmazkodik a beteg állapotához és annak változásához.

A diéta célja a dysphagiához gyakran társuló akaratlan testtömegcsökkenés, a fehérje-energia malnutritio és egyéb tápanyagok hiánya, valamint a dehidráció mérséklése vagy elkerülése [34].

A gyakorlatban (amennyiben a szájon keresztüli táplálkozás biztonságos) ez az ételek konzisztenciájának, textúrájának módosításával biztosítható. Sok esetben a folyadékok sứrítése is szükségessé válik. Ily módon biztonságosabbá tehető a nyelés, valamint csökkenthető az aspiráció veszélye [35].

Az ételkonzisztencia, -textúra fokozatainak leírása országonként különbözik [36]. A terminológia egységesítésén egy nemzetközi kezdeményezés (International Dysphagia Diet Standardisation Initiative) jelenleg is dolgozik $[37,38]$.

$A z$ ételek és italok süritéséhez általában étkezési keményítő vagy xantángumi alapú termékek állnak rendelkezésre, de előre sưrített, használatra kész készítmények 
(például italok, desszertek) is kaphatók. Jobban tolerálhatók a betegek számára az egynemú textúrájú ételek, mint a többkomponensüek [39].

Kerülni kell az alkoholt, a szélsőséges hőmérsékletű, a túl savanyú, valamint a nehezen nyelhető ételeket, italokat. Ilyenek lehetnek a száraz vagy ropogós ételek (például kekszek, chipsek), szálkás halak, pörzsanyagdús ételek (például steak), tapadós ételek (például mogyoróvaj), szénsavas italok és morzsálódós élelmiszerek. Könnyen félrenyelhetők, ezért nem javasolt a pattogatott kukorica, a héjrészt is tartalmazó gabonafélék, diófélék, rostos gyümölcsök, zöldségek (például kukorica, ananász) [40].

Egyéb problémák. Késedelmes nyelési reflex esetén a füszeres vagy a melegebb-hidegebb ételek az idegek ingerlésével segíthetik a probléma megoldását. A kis volumenû dúsított, jóízű és szépen tálalt fogások javítják az étvágyat [39].

$A$ dietetikus feladata a beteg, a hozzátartozó és a kezelőszemélyzet oktatása, a beteg állapotának követése, tápláltsági állapotának, tápanyagbeviteli értékeinek gyakori elemzése, szükség esetén étrend-kiegészítők, tápszerek ajánlása.

\section{Megbeszélés}

A beteg általános állapota primer neurológiai betegség nélkül is magyarázhatja a nyelészavar gyakoriságát, de az utóbbi évek kutatásai a közvetlen neurológiai kórokok (beleértve a gyakori stroke) szerepét is részletesen feltárták. Felismerték az ún. néma aspiráció jelentőségét, mely gyakran áll az aspirációs pneumonia hátterében, ami sokszor halálos szövődmény lehet. Ismert, hogy az akut stroke órákon belül immunológiai választ provokál a szervezetben [41, 42]. Ennek első fázisa egy túlzott reakció, melyet már másnap immunszupprimált állapot követ. Ez eleve hajlamosít gyulladásos szövődményekre. Az ún. poststroke pneumonia fogalma gyökeresen más értelmezésbe helyezte a stroke-ot követő tüdőgyulladások megítélését, jellegzetessége alapján egyértelmúen a stroke közvetlen cerebralis hatásaként alakul ki [43].

Egyértelmúvé vált a nyelészavar korai felismerésének és terápiájának szükségessége, amely nyomást gyakorolt szakmai irányelvek megalkotására [2, 3]. Ezek magyarra adaptálása is megtörtént [4]. A dysphagia vizsgálatának, szürésének a betegfelvételt követően órákon belül meg kell valósulnia. Mûszeres nyelésvizsgálatok (VFSS, FEES) is rendelkezésre állnak már, melyek jól meghatározott esetekben alkalmazandók. Az agyi érkatasztrófán átesett betegek a mindennapjaikat fogyatékossággal és akadályozottsággal élik [7]. Ezek hatással vannak a túlélők mindennapi életére és életminőségére. Negatívan befolyásolják önbizalmukat, fizikai aktivitásukat, önállóságukat, függetlenségüket és családi kapcsolataikat [10]. Eddig kevesebb figyelmet kapott, de meg kell fogalmazni: a nyelészavar egyértelmű és súlyos fogyatékosság. Ám a kapcsolat kétirányú: a stroke-betegek rossz életminősé- ge negatív hatással van tápláltsági állapotukra. Korábbi tanulmányok szerint az alultápláltság aránya magas már az akut stroke-betegek esetében is [11]. A stroke-betegek megfelelő tápláltsági állapota az eredményes rehabilitációnak, a szövődményszám csökkentésének, a rövidebb kórházi kezelésnek, az alacsonyabb mortalitásnak a záloga. A dysphagia hozzájárul a stroke-betegek alultápláltságához, a malnutritióhoz, amikor a nyelési nehezítettség vagy képtelenség miatt a tervezett napi étrendet nem vagy csak részlegesen tudják betartani. A dysphagia a betegség kimenetelének független prediktora lehet, különösen az első három hónapban. A szondatáplálás igénye szoros összefüggést mutat a mortalitással. A dysphagia malnutritióval, exsiccosissal és a kórházi tartózkodás hosszabb időtartamával jár együtt, emeli a gyógyszerköltségeket (például az antibiotikumigényt) [12]. A stroke-beteg ellátásának egyik első eleme a dysphagia szûrése. A táplálékfelvételben szerepet játszó izomcsoportok, idegek vizsgálatát követően az indirekt nyelési próbák fontosak.

A légútvédelem aktív eleme a köhögés és a torokköszörülés. Tízperces időablakban négy vagy annál kevesebb nyelés már szenzitív előrejelzője a dysphagiának [16-18]. A próbák negatív eredménye esetén direkt nyelési próbákra van szükség, preferált a GUSS-vizsgálat [19]. Táplálásterápiára akkor szorul a stroke-beteg, amikor magas a kockázata a kóros tápláltsági állapot kialakulásának, vagy már ki is alakult, és per os táplálással nem fedezhető biztonságosan a megfelelő energia-, tápanyagés folyadékbevitel [24-26 ]. Az egyénre szabott korszerü táplálásterápia megtervezéséhez a testösszetétel analizálása is szükséges $[24,25]$. BIA-eszközök segítségével a testösszetétel is könnyedén felmérhető. A dysphagia súlyosságát ismerni kell ahhoz, hogy a betegnek a személyre szabott táplálásterápia elrendelhető legyen. A táplálásterápia szempontjából ki kell emelni azokat a súlyos stroke-betegeket, akik eszméletlen állapotban gépi lélegeztetésre szorulnak az intenzív terápiás osztályon. Ideális esetben a kritikus állapotú betegek magas fehérje- és moderált energiatartalmú szondatermékkel táplálásterápiában részesülnek, adott esetben az ételek konzisztenciájának, textúrájának módosításával, a folyadékok súrítésével [33-35].

\section{Következtetés}

A stroke-ellátás teammunka esetén lehet eredményes. Az új módszerek, technikák bevezetése minden téren, így a táplálásban is speciális, eddig nem alkalmazott ismeretek bevonását jelenti az ellátásba. Ez magával hozza, hogy új szereplők lesznek részesei a teamnek: logopédus, nyelésterapeuta. A személyre szabott táplálásterápiában a dietetikus is az orvos egyenrangú partnere lesz. Feladata nem pusztán a megfelelő diéta összeállítása, hanem a beteg, a hozzátartozó és a kezelőszemélyzet oktatása, az állapot követése, a beteg tápláltsági állapotának, tápanyagbeviteli értékeinek gyakori elemzése, szükség ese- 
tén tápszerek ajánlása. Ez az út vezethet el a kitűzött cél megvalósításához: jobb és gyorsabb kórlefolyás, kevesebb szövődmény és rövidebb kórházi tartózkodás.

Anyagi támogatás: A közlemény megírása anyagi támogatásban nem részesült.

Szerzői munkamegosztás: K. A: A koncepció kidolgozása, irodalomkutatás, a kézirat előkészítése közlésre, a kézirat megírása és véglegesítése. Sz. P. T.: Szakértői feladat ellátása, irodalomkutatás, a kézirat megírása. Ó. Cs.: Irodalomkutatás, szakértői feladatok ellátása. M. A.: Szakértői feladatok ellátása, irodalomkutatás, a kézirat megírása. V. B. M.: Szakértői feladatok ellátása, irodalomkutatás, a kézirat megírása. B.-M. K. A.: Irodalomkutatás, szakértői feladatok ellátása. F. A.: A hipotézis kidolgozása, irodalomkutatás, szakértői feladatok ellátása, a kézirat megírása, előkészítése közlésre és kritikus revíziója. A cikk végleges változatát valamennyi szerző elolvasta és jóváhagyta.

Érdekeltségek: A szerzőknek a közleménnyel összefüggő érdekeltségeik nincsenek.

\section{Irodalom}

[1] Ludlow CL. Central nervous system control of voice and swallowing. J Clin Neurophysiol. 2015; 32: 294-303.

[2] Wirth R, Smoliner C, Jäger M, et al. Guideline clinical nutrition in patients with stroke. Exp Transl Stroke Med. 2013; 5: 14.

[3] Burgos R, Bretón I, Cereda E, et al. ESPEN guideline clinical nutrition in neurology. Clin Nutr. 2018; 37: 354-396.

[4] Folyovich A, Sahin P, Molnár A, et al. (eds.) [adapted and developed for use in Hungary] Healthcare professional guideline on nutritional therapy for stroke patients. Abbreviated form of the version submitted electronically to the OBDK by the Department of Neurology of the Professional College of Neurology for official procedure in July 2017. [Egészségügyi szakmai irányelv a stroke-betegek táplálásterápiájáról. A Neurológiai Szakmai Kollégium Neurológiai Tagozata által az OBDK felé hivatalos eljárásra 2017 júliusában elektronikusan benyújtott változat rövidített formája.] Ideggyogy Szle Proceedings 2017; 2: 189228. [Hungarian]

[5] Bereczki D, Csányi A, Csiba L, et al. (eds.) Healthcare professional guideline for the diagnosis and treatment of acute ischemic stroke. Abbreviated form of the version compiled and commented by the management of the Hungarian Stroke Society, submitted electronically by the Neurology Department to the OBDK in April 2017. [Egészségügyi szakmai irányelv az akut ischaemiás stroke diagnosztikájáról és kezeléséről. A Magyar Stroke Társaság vezetősége által összeállított és véleményezett, a Neurológiai Tagozat által az OBDK felé hivatalos eljárásra 2017 áprilisában elektronikusan benyújtott változat rövidített formája]. Ideggyogy Szle Proceedings 2017; 2: 58-103. [Hungarian]

[6] Truelsen T, Piechhowski-Jóźwiak B, Bonita R, et al. Stroke incidence and prevalence in Europe: a review of available data. Eur $\mathrm{J}$ Neurol. 2006; 13: 581-598.

[7] Gbiri CA, Olaware OA, Isaac SO. Stroke management: informal caregivers': burdens and strians of caring for stroke survivors. Ann Phys Rehabil Med. 2015; 58: 98-103.

[8] Mendez-Tellez PA, Nusr R, Feldman D, et al. Early physical rehabilitation in the ICU: a review for the neurohospitalist. Neurohospitalist 2012; 2: 96-105.
[9] Sackley CM, Gladman JR. The evidence for rehabilitation after severely disabling stroke. Phys Ther Rev. 1998; 3: 19-29.

[10] Smith TM, Pappadis MR, Krishnan S, et al. Stroke survivor and caregiver perspectives on post-stroke visual concerns and longterm consequences. Behav Neurol. 2018; 2018: 1463429.

[11] Lieber AC, Hong E, Putrino D, et al. Nutrition, energy expenditure, dysphagia, and self-efficacy in stroke rehabilitation: a review of the literature. Brain Sci. 2018; 8: 218.

[12] Arnold M, Liesirova K, Broeg-Morvay A, et al. Dysphagia in acute stroke: incidence, burden and impact on clinical outcome. PLOS ONE 2016; 11: e0148424.

[13] Chen PC, Chuang CH, Leong CP, et al. Systematic review and meta-analysis of the diagnostic accuracy of the water swallow test for screening aspiration in stroke patients. J Adv Nurs. 2016; 72: $2575-2586$.

[14] Dozier TS, Brodsky MB, Michel Y, et al. Coordination of swallowing and respiration in normal sequential cup swallows. Laryngoscope 2006; 116: 1489-1493.

[15] Shaker R. Oropharyngeal dysphagia. Gastroenterol Hepatol. 2006; 2: 633-634.

[16] Crary MA, Carnaby GD, Sia I, et al. Spontaneous swallowing frequency has potential to identify dysphagia in acute stroke. Stroke 2013; 44: 3452-3457.

[17] Oguchi K, Saitoh E, Mizuno M, et al. The repetitive saliva swallowing test (RSST) as a screening test of functional dysphagia ( 1 ) normal values of RSST. Jpn J Rehabil Med. 2000; 37: 375-382.

[18] Waito A, Bailey GL, Molfenter SM, et al. Voice-quality abnormalities as a sign of dysphagia: validation against acoustic and videofluoroscopic data. Dysphagia 2011; 26: 25-34.

[19] Trapl M, Enderle P, Nowotny M, et al. Dysphagia bedside screening for acute-stroke patients: the Gugging Swallowing Screen. Stroke 2007; 38: 2948-2952.

[20] Dziewas R, Baijens L, Schindler A, et al., The European Society for Swallowing Disorders. European Society for Swallowing Disorders FEES accreditation program for neurogenic and geriatric oropharyngeal dysphagia. Dysphagia 2017; 32: 725-733.

[21] Hsiao MY, Chang YC, Chen WS, et al. Application of ultrasonography in assessing oropharyngeal dysphagia in stroke patients. Ultrasound Med Biol. 2012; 38: 1522-1528.

[22] Lee JH, Kim HS, Yun DH, et al. The relationship between tongue pressure and oral dysphagia in stroke patients. Ann Rehabil Med. 2016; 40: 620-628.

[23] Britton D, Roeske A, Ennis SK, et al. Utility of pulse oximetry to detect aspiration: an evidence-based systematic review. Dysphagia 2018; 33: 282-292.

[24] Cederholm T, Jensen GL, Correia MI, et al. GLIM criteria for the diagnosis of malnutrition - A consensus report from the global clinical nutrition community. Clin Nutr. 2019; 38: 1-9.

[25] Cederholm T, Barazzoni R, Austin P, et al. ESPEN guidelines on definitions and terminology of clinical nutrition. Clin Nutr. 2017; 36: 49-64.

[26] Burgos R, Bretón I, Cereda E, et al. ESPEN guideline clinical nutrition in neurology. Clin Nutr. 2018; 37: 354-396.

[27] Kyle UG, Bosaeus I, De Lorenzo AD, et al. Bioelectrical impedance analysis - part I: review of principles and methods. Clin Nutr. 2004; 23: 1226-1243.

[28] Kyle UG, Bosaeus I, De Lorenzo AD, et al. Bioelectrical impedance analysis - part II: utilization in clinical practice. Clin Nutr. 2004; 23: 1430-1453.

[29] Thibault R, Pichard C. The evaluation of body composition: a useful tool for clinical practice. Ann Nutr Metab. 2012; 60: 6-16.

[30] Molnár A, Török É, Czuppon K, et al. (eds.) Body composition assessment in clinical practice. [Testösszetétel-analizálás a klinikai gyakorlatban.] Új Diéta 2017; 26: 15-18. [Hungarian]

[31] Molnár A, Csontos ÁA, Dakó S, et al. (eds.) Investigating the efficacy of nutrition therapy for outpatients with inflammatory bowel disease. [A táplálásterápia hatékonyságának vizsgálata 
gyulladásos bélbetegségben szenvedők gondozása során.] Orv Hetil. 2017; 158: 731-739. [Hungarian]

[32] Molnár A. Diagnostic criteria for abnormal body composition and examining the effectiveness of treatment in clinical practice. Doctoral dissertation. [Kóros testösszetétel diagnosztikus kritériumainak és a kezelés hatékonyságának vizsgálata a klinikai gyakorlatban. Doktori értekezés.] Semmelweis Egyetem, Patológiai Tudományok Doktori Iskola, Budapest, 2017. [Hungarian]

[33] Singer P, Blaser AR, Berger MM, et al. ESPEN guideline on clinical nutrition in the intensive care unit. Clin Nutr. 2019; 38: $48-79$.

[34] Sura L, Madhavan A, Carnaby G, et al. Dysphagia in the elderly: managment and nutritional considerations. Clin Interv Ageing 2012; 7: 287-298.

[35] Steele C, Alsanei WA, Ayanikalath S, et al. The influence of food texture and liquid consistency modification on swallowing physiology and function: a systematic review. Dysphagia 2015; 30: 2-26. [Erratum: Dysphagia 2015; 30: 272-273.]

[36] Beck AM, Kjaersgaard A, Hansen T, et al. Systematic review and evidence based recommendations on texture modified foods and thickened liquids for adults (above 17 years) with oropharyngeal dysphagia. An updated clinical guideline. Clin Nutr. 2018; 37: 1980-1991.

[37] Cichero JA, Lam P, Steele CM, et al. Development of international terminology and definitions for texture-modified foods and thickened fluids used in dysphagia management: the IDDSI framework. Dysphagia 2017; 32: 293-314.

[38] Lam P, Stanschus S, Zaman R, et al. The International Dysphagia Diet Standardisation Initiative (IDDSI) framework: the Kempen pilot. Br J Neurosi Nurs. 2017; 13(Suppl 2): S18.

[39] Copeman J. Dysphagia. In: Gandy J. (ed.) Manual of dietetic practice. Wiley Blackwell, Oxford, 2019; pp. 397-405.

[40] Escott-Stump S. Dysphagia. In: Escott-Stump S. Nutrition diagnosis-related care. Wolters Kluwer, Philadelphia, PA, 2015; pp. 403-406.

[41] Folyovich A, Biró E, Orbán C, et al. Relevance of novel inflammatory markers in stroke-induced immunosuppression. BMC Neurol. 2014; 14: 41.

[42] Folyovich A, Biró E, Orbán C, et al. Kvl.3 Lymphocyte potassium channel inhibition as a potential novel therapeutic target in acute ischemic stroke. CNS Neurol Disord Drug Targets 2014; 13: 801-806

[43] Hannawi Y, Hannawi B, Rao CP, et al. Stroke-accociated pneumonia: major advances and obstacles. Cerebrovasc Dis. 2013; 35: $430-443$.

(Kovács Andrea, Budapest, Kertváros út 76., 1028 e-mail: kovacs.andrea197006@gmail.com)

\section{"Animo ventrique imperare debet qui frugi esse vult." (Légy ura lelkednek és gyomrodnak, derék csak úgy lehetsz.)}

A cikk a Creative Commons Attribution 4.0 International License (https://creativecommons.org/licenses/by/4.0/) feltételei szerint publikált Open Access közlemény, melynek szellemében a cikk bármilyen médiumban szabadon felhasználható, megosztható és újraközölhető, feltéve, hogy az eredeti szerző és a közlés helye, illetve a CC License linkje és az esetlegesen végrehajtott módosítások feltüntetésre kerülnek. (SID_1) 